\title{
Verbum
}

$31(2017) 97-122$

Ks. Andrzej Piwowar

Katolicki Uniwersytet Lubelski Jana Pawła II andpiw@op.pl

\section{HARMONIA MAKROKOSMOSU \\ W SyRACHOWYM OPISIE CIAE NIEBIESKICH (SYR 43,1-10)}

The Harmony of the Universe

in Sirach's Depiction of Celestial Bodies (Sir 43:1-10)

Syr 42,15-43,33 jest hymnem na cześć Stwórcy i Jego dzieła. Mędrzec wyraża w nim zachwyt nad stworzonym światem, który jest świadectwem wielkości, wszechmocy i piękna Boga. W 43,1-10 Syrach opisuje nieboskłon i ciała niebieskie (słońce, księżyc i gwiazdy). Tekst ten wyraża przede wszystkim ich niezwykłą wielkość i piękno. Jednak gdy wczytamy się dokładnie i wnikniemy głębiej w jego grecką wersję, to odkryjemy, że mówi on również o harmonii i ładzie w makrokosmosie, które z kolei świadczą o mądrości Stwórcy. Prezentacja księżyca (43,6-8) i gwiazd (43,9-10) wyraża wprost (explicite) powyższe prawdy. Natomiast w poetyckiej prezentacji firmamentu $(43,1)$ i słońca $(43,2-5)$ zawarte są one implicite, tzn. w znaczeniu

Syr 43,1-10;

harmonia kosmosu; stworzenie; Stwórca; firmament (niebo); słońce; księżyc; gwiazdy 
takich słów, jak np. stereōma, oraz w zadaniach (funkcjach w świecie) przypisanych im przez Boga.
Abstract

Sir 42:15-43:33 constitutes a hymn celebrating the Creator and his creations. There the sage expresses his fascination with the created world, which stands as a testimony to God's greatness, might and beauty. In the passage 43:1-10 Sirach depicts the sky and its celestial bodies: the sun, moon and stars, focusing primarily on their extraordinary greatness and beauty. When the Greek version of the text is read more carefully, however, it is clear that the section mentions also the harmony and order of the universe, which are manifestations of God's wisdom. The depictions of the moon (43:6-8) and the stars (43:9-10) express these truths explicitly. In the poetic descriptions of the firmament (43:1) and the sun (43:2-5), however, they are conveyed implicitly, through the meaning of words such as e.g. stereoma, and in the functions assigned to the heavenly bodies by God.
KEYWORDS

Sir 43:1-10;

harmony of the universe; creation;

Creator;

firmament

(the sky);

sun; moon; stars.

Stworzony przez Boga świat i refleksja nad nim (teologia stworzenia) są bardzo ważne w tradycji mądrościowej Starego Testamentu ${ }^{1}$. W wielu tekstach stanowią one bowiem punkt wyjścia mędrców w ich rozważaniach nie tylko nad samą

1 „Each of the wisdom texts finds its theological center in creation” (Perdue, Wisdom and Creation, 340). „Wisdom thinks resolutely within the framework of a theology of creation” (Zimmerli, „The Place and Limit”, 316). Por. Galvagno, „Creazione”, 248; Schifferdecker, "Creation Theology", 63. 
mądrością, ale również nad Bogiem i człowiekiem. Jednym $\mathrm{z}$ wielu biblijnych tekstów sapiencjalnych, które mówią o stwórczej działalności Boga i jej efektach ${ }^{2}$, jest hymn na cześć Stwórcy i Jego dzieła zawarty w Syr 42,15-43,333. Zdaniem G. Schmidta Goeringa poemat ten jest najważniejszym tekstem dotyczącym teologii stworzenia w Syr ${ }^{4}$. W niniejszym artykule skoncentrujemy się jedynie na jego części (tj. 43,1-10), w której Syrach opisał nieboskłon i znajdujące się na nim ciała niebieskie. Tekst ten jest poetycko-mądrościowym komentarzem do kapłańskiego opisu stworzenia świata (zob. Rdz 1,1-2,4a), w sposób szczególny do czwartego dnia, w którym to Bóg stworzył słońce, księżyc i gwiazdy (zob. Rdz 1,14-19). W naszym omówieniu Syr 43,1-10 skupimy się jedynie na tych wypowiedziach, które, zgodnie z tytułem artykułu, mówią explicite lub implicite o harmonii i ładzie w makrokosmosie, tzn. ciał niebieskich oraz ich oddziaływaniu na ziemię i życie istot żyjących na niej. Nasze analizy oprzemy na własnym tłumaczeniu ${ }^{5}$ tekstu greckiego dzieła Syracha ${ }^{6}$, ponieważ właśnie ta wersja, a nie hebrajski oryginat ${ }^{7}$, została uznana za kanoniczną.

2 Wśród innych tekstów możemy wymienić: Hi 28; 38-41; Prz 8,2231 ; Ps $8 ; 19 ; 90 ; 104 ; 136 ; 147 ; 148$, a także: Syr 1,1-10; 15,11-18,14; $24,33,7-15$ oraz $39,12-35$.

3 Ważniejsze opracowania obcojęzyczne na temat Syr 42,15-43,33: Argall, 1 Enoch and Sirach, 142-154; Calduch-Benages, „L'inno al creato”, 51-66; Calduch-Benages, „The Hymn to the Creation”, 119138; Prato, Il problema della teodeicea, 116-208; Sauer, Jesus Sirach/ Ben Sira, 291-300; Sauer, Studien zu Ben Sira, 67-78; Skehan - Di Lella, The Wisdom of Ben Sira, 484-496; Zapff, Jesus Sirach, 301314; Zappella, „La contemplatione sapienziale”, 308-314. W języku polskim: Potocki, „Mądrość uczonego w Piśmie”, 195-196.

4 Zob. Schmidt Goering, Wisdom's Root, 26.

5 Inne tłumaczenia greckiej wersji Syr 43,1-12 zob. Ksieggi greckie, 671672; NETS, 754-755; Septuaginta, czyli Biblia Starego Testamentu, 1254-1255; Septuaginta Deutsch, 1149-1150.

6 Grecki tekst Syr 43,1-10 zob. Rahlfs, Septuaginta, II, 452-453; Ziegler, Sapientia Iesu Filii Sirach, 325-327.

7 Tekst hebrajski Syr 43,1-10 zawiera zarówno tekst manuskryptu B z genizy kairskiej synagogi (zob. Beentjes, The Book of Ben Sira, 75; 


\section{Firmament (Syr 43,1)}

Opis stworzonego świata w hymnie na cześć Stwórcy $(42,15-$ $43,33)$ Syrach rozpoczyna od poetyckiej prezentacji nieboskłonu, która koncentruje się na pięknie i niezwykłości tego elementu makrokosmosu i wyraża w sposób wyjątkowy zachwyt mędrca (aż trzy z czterech części tego wersetu mówią o podziwie nieba, jaki wykazuje autor):

Duma wysokości, firmament czystości, wygląd nieba, w widzeniu chwały $(43,1)$.

Werset ten pełni funkcję wprowadzenia do omówienia ciał niebieskich. Rysuje on przed oczami czytelnika nieboskłon, czyli scenę, na której pojawią się w następnych wersetach główni bohaterowie: słońce, księżyc i gwiazdy. Przedstawia więc znajdującą się nad człowiekiem przestrzeń stworzonego świata, która wzbudza w nim z jednej strony zadziwienie swą tajemniczością, z drugiej zaś zachwyt i podziw swoim pięknem.

Mówiąc o harmonii i ładzie w stworzonym przez Boga świecie, powinniśmy w 43,1 zwrócić uwagę na rzeczownik stereōma („fundament”, „oparcie”, „szkielet”, metaforycznie także „siła”, „moc”, w Biblii greckiej „,firmament nieba”), za pomocą którego zostało określone niebo (ouranos). Pochodzi on od rdzenia stereō/stereo („,czynię stałym, mocnym, trwa-

Morla, Los manuscritos hebreos, 268-272; Ben-Hayyim, The Book of Ben Sira, 50-51), jak i odnalezionego w Masadzie. Niestety ten ostatni nie jest kompletny, zwłaszcza drugie stychy zostały poważnie uszkodzone (zob. Beentjes, The Book of Ben Sira, 118-119; Morla, Los manuscritos hebreos, 435-438; Ben-Hayyim, The Book of Ben Sira, 50-51; Yadin, The Ben Sira Scroll, 186-189, 221-222).

8 Zob. Abramowiczówna, Stownik grecko-polski, IV, 103; Liddell Scott, A Greek-English Lexicon, 1640; Lust - Eynikel - Hauspie, A Greek-English Lexicon, II, 438; Montanari, Vocabolario, 1965; Muraoka, A Greek-English Lexicon, 635. 
łym"), do którego dodano przyrostek nominalny $-m a^{9}$. Słowo to wskazuje więc na coś, co jest stałe, trwałe, solidne, niezmienne (por. 1 Ezd 8,78; Es 9,29; 1 Mch 9,14; Ps 72,4 i Ez 13,5). Bardzo wymowne są dwa teksty Septuaginty z Księgi Psalmów, w których Bóg jest nazwany ostoją człowieka (kyrios stereōma w Ps 17,3 i stereōma mou w odniesieniu do Boga w 70[71],3), czyli kimś, na kim może on całkowicie polegać, kto nigdy go nie zawiedzie, ponieważ jest stały w swych postanowieniach i niezmienny w swych zamiarach. Odniesienie stereōma do YHWH pozwala nam w pełni zrozumieć znaczenie tego słowa.

Użycie stereōma w Syr 43,1a $\beta$ odsyła nas do pierwszego (według kolejności kanonicznej) opisu stworzenia świata (zwłaszcza do Rdz 1,6-8.14-18), w którym słowo to występuje aż dziewięć razy (zob. Rdz 1,6.7(3x).8.14.15.16.20) z dwudziestu jeden w całym tekście LXX ${ }^{10}$. Stanowi to ponad jedną trzecią (blisko połowę) miejsc w całym greckim tekście Starego Testamentu, w których ono się pojawia. W drugim dniu kapłańskiego opisu stworzenia świata Bóg powołał do istnienia sklepienie pośrodku wód, którego celem było oddzielenie wód górnych (znajdujących się nad sklepieniem) od wód dolnych znajdujących się na powierzchni ziemi i pod nią. Jest to drugie dzieło Boże, dzięki któremu ustanowił On podstawowy podział świata na to, co w górze (ponad człowiekiem), i na dole (wokół niego i pod jego stopami) ${ }^{11}$. Obok światła jest to najważniejsze dzieło Boże, dzięki któremu zapanował On nad

9 Zob. Romizi, Greco antico, 1176. Por. Bertram, „stereos, stereō, stereōma", 609.

10 Zob. Hatch - Redpath, A Conordance, 1289.

11 „Przedmiotem stworzenia jest (...) potężny nieboskłon (...), przypominający solidną, masywną kopułę (...), przykrywającą jakby kloszem (Ps 19,2; Hi 37,18) znajdującą się pod nim ziemię. Jego zadaniem jest «oddzielić» wody na górze od wód na dole (w. 6). Podział ma tym razem charakter przestrzenny" (Lemański, Księga Rodzaju, 154). Por. Hamilton, The Book of Genesis, 122; von Rad, Genesi, 62; Wenham, Genesis, 19; Westermann, Genesis, 117; Zapff, Jesus Sirach, 305. 
pierwotnym chaosem i uporządkował go ${ }^{12}$. Sklepienie nieba jest więc bardzo istotnym elementem kosmosu gwarantującym stworzonemu światu harmonię i ład, ponieważ zabezpiecza go i chroni przed powrotem do pierwotnego stanu nieładu ${ }^{13}$.

Na podstawie przytoczonych powyżej tekstów z Ps możemy powiedzieć w sposób metaforyczny, że firmament ma coś w sobie ze stałości i niezmienności Boga. Chodzi oczywiście tylko o analogię, a nie odniesienie realne (jedynie Najwyższy jest absolutnie stały i niezmienny - cecha ta należy do Jego istoty, nieboskłon jedynie charakteryzuje się tym przymiotem). Wobec przedstawionej powyżej analizy znaczenia greckiego rzeczownika stereōma możemy stwierdzić, że najlepszym jego tłumaczeniem na język polski jest słowo „firmament” (od lac. firmamentum - „podpora”, „umocnienie”, „podstawa”, „fundament", przenośnie „trwanie” ${ }^{14}$ ), ponieważ w swym źródłosłowie wyraża on niezachwiane, niezmienne i nienaruszalne trwanie.

Tekst grecki Syr 43,1, określając niebo za pomocą rzeczownika stereōma, jednoznacznie nawiązuje do kapłańskiego opisu stworzenia, przypisując niebu bardzo ważną rolę polegającą na zapewnieniu oraz podtrzymaniu ładu i harmonii, które Stwórca wprowadził w swe dzieło ${ }^{15}$. Nieboskłon określony jako firmament, czyli coś niezmiennego, stałego, trwałego i nieprzemijającego ${ }^{16}$, stoi na straży ustanowionego

12 Niektórzy egzegeci uważają, że pierwszy opis stworzenia świata nie mówi o stwarzaniu w ścisłym tego słowa znaczeniu, tzn. stwarzaniu ex nibilo, lecz o wprowadzaniu ładu i harmonii w istniejącą już materię (zob. Piwowar, „Biblijny opis stworzenia”, 68-75).

13 Zob. Lemański, Ksiega Rodzaju, 154.

14 Zob. Castiglioni - Mariotti, Vocabolario, 489; Jougan, Stownik kościelny, 262.

15 Zob. Zapff, Jesus Sirach, 305.

16 Do wymienionych cech nieboskłonu nawiązuje także, choć w nieco inny sposób, tekst hebrajski zarówno Rdz 1,6-8 jak i Syr 43,1, w których pojawia się rzeczownik rāqîa: , «Sklepienie» przywołuje idę̨ czegoś, co się rozpościera (Qal; Hifil), ale i wykuwa, wyklepuje z metalu (czasownik rāqa ' w osnowie Pual, por. Iz 42,5; Ps 136,6)" 
z woli Najwyższego porządku w kosmosie. Zapewnia go i nie pozwala na powrót świata do pierwotnego stanu bezładu ${ }^{17}$. W ten sposób wraz z ziemią stanowi fundament stworzonego kosmosu. Syrach wyraża tę myśl nie wprost, lecz implicite. Przesłanie zawarte w 43,1 jest jednak jednoznaczne dla uważnego i wnikliwego czytelnika tego wersetu, jeśli zna on dobrze język grecki i tekst LXX.

\section{SŁOŃCE (SYR 43,2-5)}

W poemacie na cześć Stwórcy i stworzenia Syrach w opisie ciał niebieskich zachował kolejność zawartą w Rdz 1,14-18. Po opisie nieboskłonu przedstawia słońce jako większe [ciało świecące], które zostało powołane do istnienia, aby rządziło dniem (por. Rdz 1,16):

Słońce w wyjściu głoszące w widzeniu, przedmiot wspaniały - dzieło Najwyższego.

W swoje południe wysusza kraj,

wobec jego skwaru któż się oprze?

Piec dyszący w pracach gorąca,

trzy razy więcej słońce palące góry;

parami ognistymi zionące,

(Lemański, Księga Rodzaju, 154). „In P [...], therefore, rāqîa denotes a stable, solid entity situated above the earth, which protects the living world from an influx of the waters of chaos. The noun bears the connotation «compact, firm»" (Görg, ,räqia a', räqa", 649) Por. Görg, „rāqîa', rāqa", 646-647; Hamilton, The Book of Genesis, 122; Peter, Wyktad Pisma Świętego, 225; Synowiec, Początki świata, 29; von Rad, Genesi, 61-62; Wenham, Genesis, 20; Westermann, Genesis, 117; Zapff, Jesus Sirach, 305; Zimmerli, A Commentary, 122). Firmament przedstawiony (rozumiany) jako metalowa plyta również wyraża pośrednio idę̨ stałości, niezachwiania i stabilności, choć nie aż tak wyraźnie, jak greckie stereōma.

17 Zob. Bertram, „stereos, stereoō, stereōma”, 609-610; Zapff, Jesus Sirach, 305. 
świecąc promieniami, oślepia oczy.

Wielki [jest] Pan, który je uczynił,

z powodu Jego słowa przyspiesza podróż $(43,2-5)$.

W wersetach poświęconych opisowi słońca Syrach mówi o ruchu tego ciała niebieskiego po niebie. W 43,2a odnosi się do jego wschodu (en eksodö[i] - dosł. „w wyjściu”)18, w 43,3a zaś - do południa (en mesémbria[i]), czyli najwyższego miejsca na niebie, do którego dociera w swej podróży zenit (por. $\operatorname{Rdz} 18,1 ; 2$ Sm 4,5; Syr 34,16) ${ }^{19}$. Na końcu prezentacji słońca $(43,5 b)$ stwierdza, że z powodu słowa Boga przyspiesza ono swą podróż (katespeusen poreian). Alonso Schökel i CalduchBenages uważają, że treść tego stychu odnosi się do zachodu tego ciała niebieskiego ${ }^{20}$. Jeśli interpretacja ta jest właściwa, to mędrzec z Jerozolimy przedstawił nam i opisał w sposób pełny, ze wszystkimi jego najważniejszymi momentami, dostrzegalny przez człowieka ruch słońca na nieboskłonie. Dzięki niemu po ciemnościach nocy nastaje światło dnia. W ten sposób słońce jest gwarantem równowagi (harmonii) pomiędzy tymi dwiema porami każdej doby, którą Bóg wprowadził, stwarzając w pierwszym dniu swego kosmicznego dzieła światłość (zob. Rdz 1,3-5).

W przedstawionym w Syr 43,2-5 ruchu słońca na sklepieniu nieba powinniśmy dostrzec jeszcze jeden aspekt. Podróż tej gwiazdy jest uporządkowana, harmonijna i regularna w swej powtarzalności. Nie jest zakłócana jakimiś nieregularnościami czy nieprzewidywalnym i trudnym do odgadnięcia przez człowieka zachowaniem. Regularnie, tzn. codziennie, stale

18 Zob. Calduch-Benages, „L'inno al creato”, 60

19 Zob. Calduch-Benages, „L'inno al creato”, 60; Zapff, Jesus Sirach, 306.

20 Zob. Alonso Schökel, Proverbios y Eclesiastico, 301; Calduch-Benages, "L'inno al creato", 60. Por. Argall, 1 Enoch and Sirach, 146, przyp. 361; Skehan - Di Lella, The Wisdom of Ben Sira, 492. M. Zappella sprzeciwia się jednak tej interpretacji (zob. Zappella, „La contemplatione", 309-310). 
i niezmiennie, słońce wschodzi, dobiega do najwyższego punktu na firmamencie, a następnie zmierza ku zachodowi aż do całkowitego zniknięcia za horyzontem. Choć człowiek przyzwyczaił się do takiego ruchu tego ciała niebieskiego i nie zwraca na nie uwagi, to jednak jest ono wyrazem harmonii, ładu i równowagi w stworzonym przez Boga świecie.

Syrach, przedstawiając słońce, prawie całkowicie skupił się na efekcie termicznym, który ono powoduje ${ }^{21}$. W południe wysusza ono kraj (zob. 43,3a), a ponadto pali także góry (zob. $43,4 b$ ). Nikt nie jest w stanie oprzeć się jego żarowi (zob. $43,3 b)$. Wytwarza ono na ziemi tak wysoką temperaturę, że trzykrotnie przewyższa ona tę osiąganą w piecach buchających ogniem wykorzystywanych przez rzemieślników (garncarzy czy kowali; zob. 43,4ab) w ich pracach. Chcąc podkreślić gorąco pochodzące od tego ciała niebieskiego, określa je jako zionące parą ognistą (zob. 43,3c). W powyższych słowach mędrzec bardzo mocno uwypuklił termiczne oddziaływanie słońca na ziemię i jej mieszkańców. Wysoka temperatura, którą ono wytwarza i sprowadza na ziemię, jest nie tylko uciążliwa, ale stanowi także zagrożenie dla życia wszystkich istot żyjących - może zniszczyć (wysuszyć, wypalić) zarówno rośliny, jak i zwierzęta, a nawet ludzi ${ }^{22}$. Jednak pomimo tak wielkiego i niebezpiecznego oddziaływania słońca na ziemię $\mathrm{i}$ istoty żyjące na niej, jego żar nie zabija ich. Również w tym możemy dostrzec harmonię i równowagę, która jest zachowana we wszechświecie - słońce, pomimo swej wielkiej mocy (wysokiej temperatury, którą wytwarza), nie niszczy życia na ziemi, choć czyni je trudnym i uciążliwym.

21 Zob. Calduch-Benages, „The Hymn”, 128; Gilbert M., Les cinq livres des Sages, 217; Prato, Il problema della teodeicea, 144; Sauer, Studien zu Ben Sira, 72-73.

22 Argall, interpretując Syr 43,2-5, podkreśla, że słońce jest narzędziem gniewu Boga: „With a variety of verbs, ben Sira highlights the sun's fitness as an instrument of wrath (43:2-5) (...) The sun has a punishing capacity as it carries out the word of the Lord (43,5b)" (Argall, 1 Enoch and Sirach, 146). 
W analogiczny sposób do wytwarzanej przez słońce temperatury Syrach mówi także o blasku promieni słonecznych. W 43,4d stwierdza, że świecąc, oślepia ono oczy (eklampōn aktinas amauroi ofthalmous). Blask słońca jest tak wielki, że nie można na nie patrzeć bezpośrednio (wprost). I choć w klimacie Palestyny jest on jeszcze bardziej zwielokrotniony poprzez częsty brak cienia, to jednak nie uszkadza on wzroku, powodując ślepotę. W starożytności, a zwłaszcza na Bliskim Wschodzie, intensywne promieniowanie słoneczne często było jednak przyczyną chorób oczu, a nawet ślepoty. Mędrzec dostrzega to zagrożenie, ale nie absolutyzuje go według jego słów nie zagraża ono wszystkim bez wyjątku.

Również blask słońca, podobnie jak wysoka temperatura, którą ono wytwarza na ziemi, choć jest wielki, nie jest jednak niszczący, mimo iż może sprawiać człowiekowi wiele problemów, utrudniać patrzenie, a nawet w niektórych przypadkach spowodować utratę wzroku. Także w ten sposób mędrzec wyraził harmonię w prowadzoną przez Stwórcę w Jego dzieło. Syrach, mówiąc o słońcu, dwukrotnie podkreśla, że jest ono stworzeniem, które do istnienia powołał Bóg (zob.43,2a i 43,5a).

\section{KSIĘŻYC (SYR 43,6-8)}

Zgodnie z kolejnością stwarzania ciał niebieskich, zawartą w kapłańskim opisie stworzenia świata, po przedstawieniu słońca Syrach skupia się w swym poemacie na księżycu:

Księżyc zjawia się ${ }^{23}$ we właściwym swoim czasie, w celu wskazania czasów i znaku wieczności.

Histesin (zob. Ziegler, Sapientia Iesu Filii Sirach, 326; por. A New English Translation of the Septuagint, 754; Septuaginta Deutsch, 1149). Wydanie LXX Rahlfsa zawiera lekcję en pasin („we wszystkim”; zob. Rahlfs, Septuaginta, II, 453). W naszym tłumaczeniu przyjęliśmy lekcję Zieglera, a nie Rahlfsa, ponieważ to pierwsze wydanie jest wydaniem krytycznym greckiego tekstu Syr. 
Od księżyca znak święta, źródło światła słabnącego ku zniknięciu.

Miesiąc jest zgodnie $z$ jego imieniem, rosnąc zdumiewająco w zmianie; przedmiot zastępów na wysokości, na firmamencie nieba świecąc $(43,6-8)$.

Już pierwszy stych tego tekstu $(43,6 a)$ zawiera w sobie odniesienie do harmonii i ładu makrokosmosu, które w sposób doskonały wyraża księżyc. Zjawia się on we właściwym dla siebie czasie (eis kairon autēs). Nie pojawia się na nieboskłonie w jakiejś nieokreślonej, trudnej do przewidzenia chwili, lecz w ściśle określonym momencie. Jego ruch jest więc nie tylko przewidywalny, ale także bardzo regularny. Dzięki temu jest on znakiem wskazującym zarówno upływ czasu (anadeiksis chronōn), jak i wieczności (sēmeion aiōnos). Wyznacza nie tylko przemijanie czasu, które odnosi się do krótkiego jego okresu (miesiąc czy rok), ale również do dłuższych etapów historii świata i ludzkości (wieki czy epoki). Syntagmę sémeion aiōnos (dosł. „znak wieczności”) możemy odczytać na dwa różne sposoby w zależności od roli składniowej dopełniacza aiōnos. Może on bowiem pełnić funkcję przydawki („znak wieczności”) lub zostać zinterpretowany jako genetivus hebraicus, tzn. rzeczownikowi w dopełniaczu powinniśmy nadać znaczenie przymiotnikowe („znak wieczny") ${ }^{24}$. W pierwszym przypadku syntagma ta mówiłaby o księżycu jako ciele niebieskim, które wyznacza dłuższe okresy czasu (np. epoki), w drugim zaś podkreślałaby, że jest on wieczny, tzn. niezmienny w swoim istnieniu, a co za tym idzie również we wskazywaniu czasu. Trudno jest jednoznacznie odpowiedzieć, które ze wspomnianych znaczeń sèmeion aiōnos tłumacz hebrajskiego oryginału na język grecki

24 Zob. Blass - Debrunner, Grammatica del Greco, $\$ 165$; Piwowar, Greka Nowego Testamentu, 256; Wallace, Greek Grammar, 86-88; Zerwick, Il greco, $\$ 40$. 
miał na myśli. Być może w sposób zamierzony sformułował swą myśl tak, aby zawierała ona w sobie obie przedstawione interpretacje. Tak czy inaczej oba jej znaczenia odnoszą się do harmonii stworzonego świata i doskonale wyrażają rolę, jaką w niej pełni księżyc. Należy jednak zauważyć, że czynią to na dwa różne sposoby. Księżyc jako „znak wieczności” wskazywałby na przemijanie czasu w dłuższej perspektywie jego upływu - wyznaczałby dłuższe jego okresy (wieki, epoki, ery itd.). Jako „znak wieczny” natomiast odnosiłby się do stabilności i niezmienności trwania księżyca - istnieje na zawsze i nigdy nie przestanie być widziany na niebie.

Pierwszy stych 43,7 zdaje się potwierdzać, że znaczenie sèmeion aiōnos powinniśmy odczytywać w sensie ,znak wieczności". Stwierdza on bowiem, że księżyc jest znakiem święta (sèmeion heortēs). Wyraźne i jednoznaczne odniesienie do kalendarza wskazuje nie na niezmienność (stałość, wieczność) księżyca, lecz na jego związek z upływem i przemijaniem czasu. Syrach opowiada się stanowczo i jednoznacznie za kalendarzem księżycowym i odrzuceniem kalendarza słonecznego. To „mniejsze ciało świecące”, a nie „większe”, wskazuje dni, w które pobożni Izraelici powinni obchodzić święta i uroczystości na cześć YHWH. Połączenie księżyca z kalendarzem i oparcie go na jego zmianach (fazy księżyca) jeszcze mocniej podkreśla i uwypukla regularność jego ukazywania się na nieboskłonie. W ten sposób mędrzec po raz kolejny podkreślił emfatycznie harmonię i ład panujący na firmamencie.

Znakiem i przejawem cykliczności księżyca w jego drodze po nieboskłonie są zmiany w jego wyglądzie. To właśnie na nich oparty został kalendarz. Łączność pomiędzy księżycem i kalendarzem jest tak wielka, że od tego ciała niebieskiego pochodzi nazwa miesiąca: „miesiąc zgodnie z imieniem jego jest" (mèn kata to onoma autés estin - 43,8a). Aby zrozumieć sens tego stychu, musimy powrócić do hebrajskiego oryginału, który tłumacz przełożył na język grecki. W języku tym „księżyc” jest określany rzeczownikiem yārēah, „miesiąc” zaś - yerah, przy czym ten pierwszy pochodzi od drugiego. Obie 
zaś nazwy wywodzą się od rdzenia yrh („wędrować”, „błądzić”, „podróżować” ${ }^{25}$. Księżyc pierwotnie był więc postrzegany jako podróżnik, który wędrował po niebie. Miesiąc zaś pojmowano jako drogę jego podróży po nieboskłonie od nowiu do pełni i powrotu znowu do nowiu ${ }^{26}$. W późniejszym czasie księżyc określano za pomocą słowa ḥō $\underline{d e s}$, które pierwotnie oznaczało „nów”, następnie zaś zaczęto używać również w znaczeniu „miesiąc” (1 Krl 6,38; 8,2) 27. Oba więc słowa, za pomocą których w języku hebrajskim określano „miesiąc”, są bardzo ściśle powiązane z księżycem i jego fazami.

W 43,6-8 Syrach w sposób nieco nieuporządkowany przedstawia pełną fazę księżyca. Zjawienie się tego ciała niebieskiego, o którym jest mowa w 43,6a, możemy odnieść do pierwszej części fazy księżyca, tzn. od nowiu do pełni (księżyc rosnący). Pojawia się on we właściwym czasie, tzn. zaczyna być widoczny. Do tej części fazy odnosi się również 43,8b mówiący o zdumiewającym rośnięciu księżyca w jego zmianach. Fragment 43,7b jednoznacznie określa zaś drugą część fazy (od pełni do nowiu), tzn. księżyc ubywający (ciemniejący). Tekst grecki nie przedstawia explicite pełni księżyca. Wydaje się jednak, że odniesienie do niej może być zawarte w $43,7 \mathrm{~b}$. W stychu tym występuje syntagma epi synteleia[i], którą możemy w zależności od znaczenia przyimka epi z celownikiem oraz rzeczownika synteleia rozumieć na dwa różne sposoby. W greckiej wersji Syr to ostatnie słowo może przyjmować znaczenie „zakończenie”, „kres” (zob. $11,27 ; 21,9 ; 22,10 ; 33,24 ; 37,11 ; 38,28.28 ; 40,14 ; 43,27)$ lub „uwieńczenie”, „perfekcja”, „doskonałość” (zob. 21,11; 45,8;

Zob. Clements, „yārēah; yerah", 355-362. Por. Massouh - Verhoef, "yerah", 540-541; de Vaux, Instytucje Starego Testamentu, 197, 203. Zob. Clements, „yärēah; yerah", 360.

27 Zob. Calduch-Benages, „L'inno”, 60; Crenshaw, „The Book of Sirach”, 834; Duesberg - Fransen, Ecclesiastico, 291; Minissale, Siracide, 204-205; North, „chädhäsh, chödhesh”, 229-233; Skehan - Di Lella, The Wisdom of Ben Sira, 493; Snaith, Ecclesiasticus, 213; de Vaux, Instytucje Starego Testamentu, 197; Zapff, Jesus Sirach, 307. 
$47,10 ; 50,11 \cdot 14)^{28}$. W kontekście 43,7b synteleia może oznaczać zarówno zakończenie świecenia księżyca (powrót do kolejnego nowiu - pierwsze znaczenie) lub jego pełnię jako najdoskonalszy jego blask (drugie znaczenie, które wyraża perfekcję i doskonałość, czyli najjaśniejszy blask tego ciała niebieskiego, jego pełnię). Przyimek epi z datiwem może przyjmować znaczenie „ku” lub „po”. Końcową część 43,7b możemy zatem rozumieć w znaczeniu „ku końcowi, kresowi”29 lub „po doskonałości”, czyli „po pełni” ${ }^{30}$.

Syrach wyraża swój zachwyt nad zmiennością księżyca. Nie jest ona jednak tylko znakiem tajemnicy (jakiegoś zakrytego przed człowiekiem i niezrozumiałego działania), którą on wyraża, ale również, a może nawet przede wszystkim, znakiem harmonii i ładu wpisanego przez Stwórcę w swoje dzieło.

W 43,6-8 możemy dostrzec jeszcze jedno nawiązanie do istniejącego w makrokosmosie porządku, który wyraża księżyc. W 43,8c zostaje on nazwany przedmiotem zastępów na wysokościach (skeuos parembolōn en hypsei). Pierwotnie rzeczownik parembolé posiadał znaczenie militarne („obozowisko”, „grupa żołnierzy gotowych do walki” lub „grupa ludzi wspólnie podróżujących" $\left.{ }^{\prime 1}\right)$. Odnosząc się początkowo do obozu wojskowego lub grupy (oddziału) żołnierzy, wskazuje pośrednio na ład i porządek, albowiem wojsko charakteryzowało się zawsze wielkim uporządkowaniem i dobrą koordynacją działań, które zapewniają zwycięstwo $\mathrm{w}$ bitwie i sprawne funkcjonowanie w czasie pokoju. Skoro

Zob. Lust - Eynikel - Hauspie, A Greek-English Lexicon, II, 460; Montanari, Vocabolario della lingua greca, 2055; Muraoka, A GreekEnglish Lexicon, 659-660.

29 Zob. A New English Translation of the Septuagint, 755; Septuaginta Deutsch, 1149.

30 Zob. Ksiegigreckie, 671; Septuaginta, czyli Biblia Starego Testamentu, 1255.

31 Zob. Liddell - Scott, A Greek-English Lexicon, 1335; Lust - Eynikel - Hauspie, A Greek-English Lexicon, II, 358; Montanari, Vocabolario della lingua greca, 1591; Muraoka, A Greek-English Lexicon, 533; Romizi, Greco antico, 941. 
księżyc przynależy, tzn. jest częścią zastępów (wojska, obozu wojskowego) na wysokościach (dość charakterystyczne określenie dla ciał niebieskich w Starym Testamencie; zob. Rdz 2,1; Pwt 4,19; 17,3; Iz 24,21; 34,4; 40,26; Dn 8,10), to również on tworzy i wpisuje się w harmonię, ład i porządek, które w nich panują. Nie jest on tylko bierną częścią uporządkowania i harmonii wprowadzonych przez Stwórcę do firmamentu niebieskiego, który jest zorganizowany precyzyjnie jak wojsko, ale równocześnie on je tworzy - jest czynnym elementem wpływającym i tworzącym harmonię oraz ład, a wyrażającym je poprzez swoją regularną zmienność.

Także poprzez dwukrotne odniesienie do blasku księżyca (zob. 43,7b i 43,8d) Syrach pośrednio mówi o ładzie i harmonii panujących w makrokosmosie. W 43,4d stwierdza, że słońce świeci tak mocno, że oślepia oczy. Jest ono najjaśniejszym ciałem niebieskim na nieboskłonie. Według mędrca również księżyc jest źródłem światła (zob. 43,7b), które świeci na firmamencie nieba (zob. 43,8d). Choć oba ciała niebieskie świecą, to jednak nie ma pomiędzy nimi żadnej rywalizacji. Co więcej, wydaje się, że możemy chyba stwierdzić, iż światło księżyca jest podporządkowane temu pochodzącemu od słońca. Pierwsze mędrzec opisuje jako słabnące (meioumenos), drugie jest zaś o wiele bardziej intensywne od blasku księżyca, tak że oślepia oczy. Interesujący jest fakt, że zarówno światło pochodzące od słońca, jak i to od księżyca, określone są przy użyciu tego samego czasownika eklampō („rozbłyskiwać”, ,jaśnieć”, „błyszczeć”), tak jakby miały one tę samą naturę (choć dziś wiemy, że jest inaczej - księżyc nie emituje światła, lecz jedynie odbija to pochodzące od słońca). Jednak w wypadku światła gwiazd tłumacz hebrajskiego pierwowzoru użył czasownika fōtidzō (znaczenie nieprzechodnie: „świecić”, „oświetlać).

Jak widać z przedstawionej krótkiej analizy opisu księżyca w Syr 43,6-8, jest on wyjątkowym i niezwykłym świadkiem harmonii i ładu w makrokosmosie ${ }^{32}$. Najbardziej widoczne są 
one w jego zmianach, które są tak bardzo regularne, że stały się podstawą do wyznaczania upływu czasu (kalendarz) ${ }^{33}$. Ową zmienność tego ciała niebieskiego obserwujemy na firmamencie, który jest postrzegany i rozumiany jako niezmienny i stały. Na tym tle jest ona tym bardziej uderzająca obserwatora. Również owo zderzenie się stałości i niezmienności firmamentu z regularną zmiennością księżyca jest wyrazem harmonii i ładu panujących w makrokosmosie. Pomimo zmian „mniejszego ciała świecącego” pozostaje ciągle zachowana stabilność nieboskłonu. Obie te rzeczywistości i stany idealnie współgrają ze sobą. Pozostając obok siebie, nie naruszają ani nie niszczą wzajemnego wspólistnienia.

\section{GWiazdy (Syr 43,9-10)}

Ostatnimi ciałami niebieskimi, które Syrach opisał w hymnie pochwalnym na cześś Stwórcy i stworzenia (Syr 42,15-43,33), są gwiazdy. Poświęcił im jednak o wiele mniej miejsca niż słońcu i księżycowi ${ }^{34}$ :

Chwała gwiazd [jest] pięknem nieba, ozdoba świecąca na wysokościach Pana.

$\mathrm{Z}$ powodu słowa Świętego będą stały zgodnie z postanowieniem

i nigdy nie ustaną w trzymaniach przez nie straży $(43,9-10)$.

To, co zostało powiedziane o księżycu jako przynależącym do zastępów na wysokościach (zob. 43,8c), powinniśmy odnieść również do gwiazd, ponieważ to właśnie one

33 Zob. Calduch-Benages, „The Hymn ”, 129; Sauer, Studien, 73; Zapff, Jesus Sirach, 307.

34 Sauer uważa, że Syrach poświęcił gwiazdom tak mało miejsca, ponieważ poprzez to chciał wyrazić i podkreślić swój sprzeciw wobec astrologii ludów starożytnego Bliskiego Wschodu i Grecji (zob. Sauer, Studien zu Ben Sira, 73). Por. Calduch-Benages, „The Hymn”, 130-133. 
stanowiły główną ich część i najliczniejszą wśród nich grupę. Harmonia i ład, o którym implicite mówi parembolé, dotyczy zatem także tej kategorii ciał niebieskich ${ }^{35}$.

W 43,10a Syrach stwierdza, że gwiazdy będą stały, trwały (stêsontai), czyli nie ulegną żadnej zmianie. Czasownik histêmi, od którego pochodzi stêsontai w znaczeniu nieprzechodnim, może posiadać również znaczenie „stać mocno”, „ostać się”, „trwać”. Zdaje się, że wyraża on zatem nie zwykłe istnienie, lecz takie, które posiada aspekt pewności, niezawodności, stałości i trwałości ${ }^{36}$. Na tej podstawie możemy powiedzieć, że mędrzec postrzega gwiazdy jako ciała niebieskie, których istnienie i miejsce w stworzonym kosmosie jest niezmienne i nienaruszalne. Powinniśmy ponadto zwrócić uwagę także na formę morfologiczną stêsontai. Jest to indicativus futuri medii trzeciej osoby liczby mnogiej. Może on wyrażać zarówno czas przyszły niedokonany („będą stały”), jak również dokonany („,ostoją się”, tzn. wytrwają, nie ulegną zmianie ${ }^{37}$. Jeśli stêsontai odczytamy w drugim z podanych znaczeń, to niepodlegające zmianie istnienie gwiazd zostaje jeszcze bardziej podkreślone poprzez pewność, że nie ulegną żadnej zmianie ich miejsca na firmamencie. Na tym jednak nie koniec. Stronę medialną, w której został wyrażony czasownik histēmi w 43,10a, powinniśmy traktować jako stronę medialną wzajemności ${ }^{38}$. Jeśli nasza interpretacja jest poprawna i słuszna, to oznaczałoby to, że trwanie gwiazd,

35 „Al pari della luna, gli astri si caratterizzano per il loro splendore e per il ricorso a un'immagine militare $(43,10)$ ” (Zappella, „La contemplatione", 310). Zob. Alonso Schökel, Proverbios y Eclesiastico, 302; Pérez Rodríguez, „Eclesiástico”, 1268; Prato, Il problema della teodeicea, 185.

36 Zob. Grundmann, „stēkō, histēmi”, 641-646; Muraoka, A GreekEnglish Lexicon, 343.

37 Zob. Blass - Debrunner, Grammatica, \$348; Piwowar, Greka Nowego Testamentu, 89; Wallace, Greek Grammar, 566-567; Zerwick, Il greco, $\$ 277$.

38 Zob. Piwowar, Greka Nowego Testamentu, 211; Wallace, Greek Grammar, 427. 
o którym jest mowa w tym stychu, dotyczy oddziaływania ich na siebie nawzajem. Przesłanie 43,10a możemy odczytać więc jako pewność, że gwiazdy nie zmienią swoich położeń wzajemnie wobec siebie - jedne w stosunku do drugich. W ten bardzo wyrafinowany sposób tekst grecki uwydatniałby i opisywałby harmonię i ład, który nigdy nie ulegnie zmianie na nieboskłonie (firmamencie).

Drugi stych 43,10 emfatycznie podkreśla myśl wyrażoną w pierwszym. Stwierdza bowiem, że gwiazdy „nigdy nie ustaną w trzymaniach straży przez nie" (ou mé eklythösin en fylakais autōn). W pierwszej części 43,10b tłumacz grecki posłużył się znaną w języku greckim konstrukcją ou $m \bar{e}+$ coniunctivus (w tym wypadku eklythōsin). Stanowi ona emfatycznie wyrażoną negację, która odnosi się do przyszłości. Za jej pomocą wyrażano subiektywną pewność, że jakaś czynność lub działanie z całą pewnością nigdy nie zostaną dokonane (nie dojdą do skutku) ${ }^{39}$. Czynnością tą w 43,10b jest ustanie w trzymaniu straży (ekluomai en fylakais). Powraca słownictwo pochodzące z języka militarnego (fylakē; por. Ba 3,34). W 43,8c mowa była o zastępach niebieskich, do których należą także gwiazdy. Jeśli weźmiemy pod uwagę, że występujący tam rzeczownik parembolē może posiadać także znaczenie „obozowisko żołnierzy”, to zadanie gwiazd, o którym mowa jest w 43,10b, jest jak najbardziej zrozumiałe. Właśnie w tym kontekście powinniśmy odczytywać i analizować treść omawianego stychu. Gwiazdy trwają na straży, to znaczy gwarantują i zapewniają bezpieczeństwo wojsku niebieskiemu, którym są one same wraz ze słońcem i księżycem oraz innymi ciałami niebieskimi. Ich zadaniem jest zabezpieczenie spokoju i ładu całego obozowiska, którym jest firmament. Czuwają one nad nim i zapewniają jego integralność i nienaruszalność. Gwarantują więc mu stabilność i trwanie w takim stanie, w jakim został on 468-469; Zerwick, Il greco, $\$ 444$. 
zorganizowany ${ }^{40}$. Tekst podkreśla niezmienność, aby nie powiedzieć wieczność, wytrwania ich w powierzonym im zadaniu („nigdy nie ustaną").

43,10a wskazuje jednoznacznie na Tego, który powierzył im to zadanie. Jest nim Święty (hagiou). Z powodu Jego słowa (en logois) będą one wiecznie trzymały straż nad obozowiskiem (wojkkiem niebieskim). Syntagmę en logois powinniśmy zinterpretować jako dativus causae (celownik przyczyny) ${ }^{41}$, ponieważ wpisuje się on najlepiej w kontekst 43,10a. W ten sposób wskazuje on na Tego, który gwiazdom nadał i przypisał funkcję, jaką mają one pełnić w makrokosmosie (kata krima w domyśle autou - Jego ${ }^{42}$.

Ostatnie dwa wersety $43,1-10$ poświęcone opisowi gwiazd stanowią nawiązanie do początkowego wersetu tej perykopy $(43,1)$. Firmament został tam ukazany jako stały i niezmienny. Zadaniem gwiazd jest zaś zapewnienie, aby ta stałość nie została w żaden sposób naruszona. W ten sposób tekst, wychodząc od idei harmonijnej trwałości firmamentu, powraca do niej w 43,10. Tworzy więc ona inkluzję Syrachowej prezentacji nieboskłonu i znajdujących się na nim ciał niebieskich.

\section{ZAKOŃCZENIE}

W Syr 43,1-10 mędrzec zachwyca się przede wszystkim wspaniałością i pięknem stworzonego przez Boga nieboskłonu i znajdujących się na nim ciał niebieskich. Budzą

40 „Ähnlich wie der Mond hinsichtlich der Zeiten (vgl. 6f.), so gelten Sirach auch die Sterne als «Wächter» und damit Garanten der von Gott gesetzten Ordnung des Himmels" (Zapff, Jesus Sirach, 308). Por. Prato, Il problema della teodeicea, 185-186; Sauer, Jesus Sirach/ Ben Sira, 298.

41 Zob. Blass - Debrunner, Grammatica, $\$ 196$; Wallace, Greek Grammar, 167-168; Zerwick, Il greco, $\$ 58$.

42 Zob. Sauer, Jesus Sirach/Ben Sira, 298; Schmidt Goering, Wisdom's Root, 28. 
one jego zachwyt i podziw, który w dalszej części poematu wyraża się uwielbieniem Stwórcy za Jego dzieło $(43,27-33)^{43}$. W opisie firmamentu, słońca, księżyca i gwiazd tekst grecki wyraża również harmonię i ład, który Stwórca wpisał w swe dzieło. Grecka wersja Syr mówi o tym zarówno explicite, jak i implicite. Idea ta najbardziej widoczna jest w opisie księżyca i gwiazd, nieco mniej w prezentacji słońca i samego nieboskłonu. W przypadku tych dwóch ostatnich dzieł Boga aluzje i nawiązania do harmonii oraz ładu makrokosmosu są ukryte w tekście. Odczytanie ich wymaga dobrej znajomości zarówno tekstu samej Biblii, jak i języka greckiego.

Syrach, mówiąc o harmonii i ładzie dostrzegalnych w makrokosmosie lub czyniąc do nich aluzje i dając je pośrednio do zrozumienia, chce skierować uwagę czytelnika na Boga - Stwórcę wszystkiego (por. 43,33) ${ }^{44}$. One świadczą bowiem w sposób szczególny o Jego mądrości ${ }^{45}$. Bóg nie tylko powotał do istnienia firmament i wszystkie byty znajdujące się na nim (wszechmoc - zob. 43,2a.5a), ale wprowadził także w nie ład i harmonię (prawa przyrody), które gwarantują ich wspólistnienie i dobre oddziaływanie na ziemię oraz jej mieszkańców. To dzięki Jego słowu i postanowieniu (zob. 43,10a) cały makrokosmos stanowi spójną jedność, która jest przeciwieństwem początkowego chaosu ${ }^{46}$.

43 platione", 313.

44 degli esseri creati trova il suo punto di raccordo nella volontà divina; il creato manifesta la divinità del suo Creatore (...) L'intento del poema, quindi, non è quello di offrire una celebrazione estetizzante dell'armonia del cosmo e dei suoi fenomeni, bensì di invitare il lettore/ascoltatore a contemplare il Creatore la sua impenetrabile azione creatrice” (Zappella, „La contemplatione”, 311-312).

45 Zob. Calduch-Benages, „God, Creator of All”, 97; Zapff, Jesus Sirach, 305.

46 Zob. Schmidt Goering, Wisdom's Root, 31. 
Abramowiczówna Z. (red.), Stownik grecko-polski (Warszawa: Państwowe Wydawnictwo Naukowe 1958) I-IV.

Alonso Schökel L., Proverbios y Eclesiastico (Los Libros Sagrados 11; Madrid: Ediciones Cristiandad 1968).

Argall R.A., 1 Enoch and Sirach. A Comparative Literary and Conceptual Analysis of the Themes of Revelation, Creation and Judgment (Society of Biblical Literature. Early Judaism and Its Literature 8; Atlanta, GA: Scholars Press 1995).

Beentjes P.C., The Book of Ben Sira in Hebrew. A Text Edition of all Extant Hebrew Manuscripts and a Synopsis of all Parallel Hebrew Ben Sira Texts (Supplements to Vetus Testamentum LXVIII; Leiden - New York, NY - Köln: Brill 1997).

Ben-Hayyim Z., The Book of Ben Sira. Text, Concordance and an Analysis of the Vocabulary (The Historical Dictionary of the Hebrew Language; Jerusalem: The Academy of the Hebrew Language and the Shrine of the Book 1973).

Bertram G., "fylassō, fylake", Theological Dictionary of the New

Testament (red. G. Kittel) (Grand Rapids, MI: Eerdmans 1995) IX, 236-244.

Bertram G., „stereos, stereoō, stereōma”, Theological Dictionary of the New Testament (red. G. Kittel) (Grand Rapids, MI: Eerdmans 1995) VII, 609-614.

Blass F. - Debrunner A., Grammatica del Greco del Nuovo

Testamento (Introduzione allo studio della Bibbia. Supplementi 2; Brescia: Paideia ${ }^{2}$ 1997).

Calduch-Benages N., „God, Creator of All [Sir 43:27-33]”, Ben Sira's God. Proceedings of the International Ben Sira Conference, Durham - Ushaw College 2001 (red. R. Egger- Wenzel) (BZAW 321; Berlin - New York, NY: Walter de Gruyter 2002) 79-117. Calduch-Benages N., „L'inno al creato (Sir 42,15-43,33)”, Parola, Spirito e Vita 44 (2001) 51-66.

Calduch-Benages N., "The Hymn to the Creation (Sir 42:1543:33): A Polemic Text?", The Wisdom of Ben Sira. Studies in Tradition, Redaction and Theology (red. A. Passaro - G. Bellia) 
(Deuterocanonical and Cognate Literature Studies 1; Berlin - New York, NY: Walter de Gruyter 2008) 119-138.

Castiglioni L. - Mariotti S., Vocabolario della lingua latina (Torino: Loescher Editore ${ }^{3} 2001$ ).

Clements R.E., "yareeah; yerah", Theological Dictionary of the Old Testament (red. G.J. Botterweck - H. Ringgren) (Grand Rapids, MI - Cambridge: Eerdmans 2006) VI, 355-362.

Crenshaw J.L., ,The Book of Sirach. Introduction, Commentary, and Reflections", The New Interpreter's Bible (ed. L.E. Keck) (Nashville, TN: Abingdon 1997) V, 603-867.

Duesberg H. - Fransen I., Ecclesiastico (La Sacra Bibbia; Roma: Marietti 1966).

Galvagno G, „Creazione”, Temi teologici della Bibbia (R. Penna G. Perego - G. Ravasi) (Cinisello Balsamo: San Paolo 2010) 246-254.

Gilbert M., Les cinq livres des Sages (Lire la Bible 129; Paris: Cerf 2003).

Görg M., „räqîa', räqa", Theological Dictionary of the Old Testament (red. G.J. Botterweck - H. Ringgren - H.J. Fabry) (Grand Rapids, MI - Cambridge: Eerdmans 2006) XIII, 646-653.

Grundmann W., „stēkē, histèmi”, Theological Dictionary of the New Testament (red. G. Kittel) (Grand Rapids, MI: Eerdmans 1995) VII, 636- 653.

Hamilton V.P., The Book of Genesis. Chapters 1-17 (The New International Commentary on the Old Testament; Grand Rapids, MI: Eerdmans 1990).

Hatch E. - Redpath H.A., A Concordance to the Septuagint and the Other Greek Versions of the Old Testament (Including the Apocryphal Books) (Grand Rapids, MI: Baker Books $\left.{ }^{2} 1998\right)$. Jougan A., Stownik kościelny tacińsko-polski (Warszawa: Wydawnictwo Archidiecezji Warszawskiej 1992).

Księgi greckie. Przektad interlinearny z kodami gramatycznymi i indeksem form podstawowych (tłum. M. Wojciechowski) (Prymasowska Seria Biblijna; Warszawa: Vocatio 2008).

Lemański J., Ksiega Rodzaju (Nowy Komentarz Biblijny. Stary Testament I/1; Częstochowa: Edycja Świętego Pawta 2013). 
Liddell H.G. - Scott R., A Greek-English Lexicon (Oxford: Clarendon Press $\left.{ }^{10} 1996\right)$.

Lust J. - Eynikel E. - Hauspie K., A Greek-English Lexicon of the Septuagint (Stuttgart: Deutsche Bibelgesellschaft 1996) I-II. Massouh S.B. - Verhoef P.A., „yerah", New International Dictionary of Old Testament Theology and Exegesis (red. W.A. VanGemersen) (Carlise: Paternoster Press 1996) II, 540-541.

Minissale A., Siracide (Ecclesiastico) (Nuovissima versione della Bibbia 23; Cinisello Balsamo: San Paolo ${ }^{32002) .}$

Montanari F., Vocabolario della lingua greca (Torino: Loescher 22004).

Morla V., Los manuscritos hebreos de Ben Sira. Traducción y notas (Asociación Bíblica Española 59; Estella: Editorial Verbo Divino 2012).

Muraoka T., A Greek-English Lexicon of the Septuagint (Louvain - Paris - Walpole, MA: Peeters 2009).

A New English Translation of the Septuagint and the Other Greek Translations Traditionally Included under that Title (red. A. Pietersma - B.G. Wright) (New York, NY - Oxford: Oxford University Press 2007) (=NETS).

North R., „chädhāsh, chödhesh”, Theological Dictionary of the Old Testament (red. G.J. Botterweck - H. Ringgren) (Grand Rapids, MI - Cambridge: Eerdmans 2006) IV, 225-244.

Perdue L.G., Wisdom and Creation: The Theology of Wisdom Literature (Nashville, TN: Abindon 1994).

Pérez Rodríguez G., „Eclesiástico”, Biblia Comentada IV. Libros Sapienciales (Biblioteca de Autores Cristianos 218; Madrid: La Editorial Catolica ${ }^{2}$ 1967) 1072-1307.

Peter M., Wyktad Pisma Świętego Starego Testamentu (Poznań Warszawa: Pallottinum 1970).

Piwowar A., „Biblijny opis stworzenia świata i człowieka w odniesieniu do nauk przyrodniczych", Naukowy a religijny obraz początku wszechświata i cztowieka. Perspektywy dialogu (red. J. Golbiak - K. Jasiński - W. Kotowicz) (Olsztyn: Wydział Teologii UWM 2015) 49-95. 
Piwowar A., Greka Nowego Testamentu. Gramatyka (Biblioteka „Verbum Vitae” 1; Kielce: Biblioteka „Verbum Vitae” 2010). Potocki S., „Mądrość uczonego w Piśmie (Księga Syracha)”, Mądrość starotestamentowego Izraela (red. S Potocki - J. Warzecha T. Brzegowy - B. Poniży) (Wprowadzenie w Myśl i Wezwanie Ksiąg Biblijnych 6; Warszawa: Wydawnictwo Akademii Teologii Katolickiej 1999) 161-204.

Prato G.L., Il problema della teodeicea in Ben Sira (AnBib 65;

Rome: Pontifical Biblical Institute 1975).

von Rad G., Genesi (Antico Testamento 2/4; Brescia: Paideia ${ }^{2} 1978$ ). Rahlfs A. (red.), Septuaginta. Id est Vetus Testamentum graece iuxta LXX interpretes I-II (Stuttgart: Deutsche Bibelgesellschaft 1979). Sauer G., Jesus Sirach/Ben Sira (Das Alte Testament Deutsch.

Apokryphen 1; Göttingen: Vandenhoeck \& Ruprecht 2000). Romizi R., Greco antico. Vocabolario greco italiano etimologico e ragionato (Bologna: Zanichelli ${ }^{3} 2007$ ).

Sauer G., Studien zu Ben Sira (BZAW 440; Berlin - Boston: Walter de Gruyter 2013).

Schifferdecker K., "Creation Theology”, Dictionary of the Old Testament: Wisdom, Poetry and Writings (red. T. Longman III - P. Enns) (Downers Grove, IL - Nottingham: IVP Academic 2008) 63-71.

Schmidt Goering G., Wisdom's Root Revealed. Ben Sira and the Election of Israel (Supplements to the Journal for the Study of Judaism 139; Leiden - Boston: Brill 2009).

Septuaginta czyli Biblia Starego Testamentu wrazz ksiegami deuterokanonicznymi i apokryfami (tłum. R. Popowski) (Prymasowska Seria Biblijna; Warszawa: Vocatio 2013).

Septuaginta Deutsch. Das griechische Alte Testament in deutscher Übersetzung (red. W. Kraus - M. Karrer) (Stuttgart: Deutsche Bibelgesellschaft 2009).

Skehan P.W. - Di Lella A.A., The Wisdom of Ben Sira (Anchor Bible 39; New York, NY: Doubleday 1987).

Snaith J.G., Ecclesiasticus or The Wisdom of Jesus Son of Sirach (The Cambridge Bible Commentary; Cambridge: Cambridge University Press 1974). 
Synowiec J., Poczattki świata i ludzkości wedtug Księgi Rodzaju

(Kraków: Bratni Zew ${ }^{32001) .}$

Wallace D.B., Greek Grammar beyond the Basics. An Exegetical

Syntax of the New Testament (Grand Rapids, MI: Zondervan 1996).

Wenham G.J., Genesis 1-15 (Word Biblical Commentary 1; Waco, TX: Word Books 1987).

Westermann C., Genesis 1-11 (A Continental Commentary; Minneapolis, MN: Fortress Press 1994).

de Vaux R., Instytucje Starego Testamentu (Poznań: Pallottinum 2004).

Yadin Y. - Talmon S., The Ben Sira Scroll from Masada. Masada

VI. Yigael Yadin Excavations 1963-1965: Final Reports. Hebrew

Fragments from Masada. The Ben Sira Scroll from Masada (The

Masada Reports 6; Jerusalem: Israel Exploration Society 1999).

Zapff B.M., Jesus Sirach 25-51 (Die Neue Echter Bibel. Alten

Testament; Echter: Echter Verlag 2010).

Zappella M., „La contemplatione sapienziale di Dio creatore (Sir 42-43)", Libri sapienziali (red. M. Priotto) (Parole di vita 8;

Padova: Messaggero di sant'Antonio 2015) 308-314.

Zerwick M., Il greco del Nuovo Testamento (Subsidia Biblica 38;

Roma: Gregorian \& Biblical Press 2010).

Ziegler J., Sapientia Iesu Filii Sirach (Septuaginta. Vetus Testamentum

Graecum Auctoritate Academiae Scientiarum Gotteingensis editum XII/2; Göttingen: Vandenhoeck\&Ruprecht ${ }^{2} 1980$ ). Zimmerli W., A Commentary on the Book of the Prophet Ezekiel, Chapters 1-24 (Hermeneia; Philadelphia, PA: Fortress Press 1979).

Zimmerli W., ,The Place and Limit of the Wisdom in the Framework of the Old Testament Theology", Studies in Ancient Israelite Wisdom (red. H.M. Orlinsky - J.L. Crenshaw) (New York, NY: KTAV 1976) 314-326.

Ks. Andrzej Piwowar, prezbiter archidiecezji warmińskiej, doktor habilitowany teologii, studiował pod kierunkiem prof. 
Maurice'a Gilberta SJ na Papieskim Instytucie Biblijnym w Rzymie (licencjat 2001) i Papieskim Uniwersytecie Gregoriańskim (doktorat 2006), adiunkt w Katedrze Egzegezy Ksiąg Historycznych, Prorockich i Sapiencjalnych INB KUL, wykładowca języka greckiego Nowego Testamentu. Polem jego badań biblijnych są księgi mądrościowe Starego Testamentu. Ostatnia publikacja: Sktadnia jezyka greckiego Nowego Testamentu (Materiały pomocnicze do wykładów z biblistyki 13; Lublin: Wydawnictwo KUL 2016; wyd. drugie poprawione 2017). 